\title{
UJI PREKLINIS VIRGIN COCONUT OIL TERHADAP PENINGKATAN KADAR KOLESTEROL BAIK HDL, PENURUNAN KADAR TRIGLISERIDA, PROFIL KIMIA ASAM LEMAK (C6-C18) DAN OMEGA-3 PADA SERUM DARAH TIKUS PUTIH (Mus musculus)
}

\author{
${ }^{1}$ Sumaryati Syukur, ${ }^{1}$ Rina Dahlyanti, ${ }^{1}$ Titi Sumanti, ${ }^{1}$ Yulia Murni, ${ }^{1}$ Zoni Hidayat, \\ ${ }^{2}$ Helmi Arifin, ${ }^{3}$ Endang Purwati, ${ }^{4}$ Risfaheri \\ ${ }^{1}$ Laboratorium Biokimia/Bioteknologi Jurusan Kimia FMIPA-UNAND Padang \\ ${ }^{2}$ Laboratorium Farmakologi Jurusan Farmasi FMIPA-UNAND Padang \\ ${ }^{3}$ Laboratorium Nutrisi Ternak FATERNA-UNAND Padang \\ ${ }^{4}$ Laboratorium LITBANG Pasca Panen Dep.Pertanian Cimanggu, Bogor
}

\begin{abstract}
The Virgin Coconut Oil (VCO) products have different qualities and controversy effects of lipids metabolism. This research has been used one of VCO product that was produced by fermentation method using Lactobacillus sp. It has high amount of lauric acid (C12) up to $51 \%$, caprilic acid (C8) $8.9 \%$, capric acid (C10) $7 \%$ include Omega-3, 6 and 9, vitamins A, D, E, K and three kinds of phytohormone. The ratio of Omega-3 and 6 was very proportional, therefore it is important to investigate the Pre Clinic Test of animal experiment. Pre Clinic Test of dietary VCO as food supplement has been determined by using 40 mice's, which divided into 4 groups. Feeding on egg yolk to Group I (negative control), Group II (positive control) increased cholesterol level. The others were Group III (egg yolk and VCO $2 \%$ ) and group IV (egg yolk and VCO 4 \%). It was determined the total of cholesterol, HDL at $10^{\text {th }}, 20^{\text {th }}$ and $30^{\text {th }}$ day treated by using the enzymatic methods. The dietary of VCO $2-4 \%$ resulted in significant increases in HDL levels from $32 \%$ to $69 \%$. The dietary of VCO $4 \%$ for four weeks did not toxic to mice metabolism. Triglycerides level decreased $50 \%$ from 177 to 85 and similar resulted to cholesterol ratio. Feeding on VCO for 4 weeks, the SCFA and MCFA not detected in serum of mice. The LCFA (C16) palmitate in significant decreased from 0.96 to $0.1 \%$. The significant level of Omega-3 increased more than three times in serum of mice dietary VCO 2-4 \%.
\end{abstract}

Keywords: Coconut Oil, Lactobacillus

\section{DAFTAR KEPUSTAKAAN}

1. Sumaryati Syukur, 2004, Bioteknologi Virgin Coconut Oil dan Potensi Kandungan Zat Anti Mikroba dan Virus, Workshop Bioteknologi/ Biomolekuler., Padang.

2. Sumaryati Syukur, Endang Purwati dan Iman Rahayu, 2005, Effectiveness Pathogen Bacteria of Virgin Coconut Oil, Proceeding Asian Congress of Microbiology, September, Bali, 1-7.

3. Sumaryati Syukur, Rina Dahlyanti, Titi Sumanti, Helmi Arifin, Endang Purwati, Risfa Heri, 2005, Biokimia dan Metabolisme Lipid MCT pada Virgin Coconut Oil VCO pada Tikus Percobaan,
Proceeding Seminar Nasional VII dan Kongres X Perhimpunan Biokimia dan Biologi Molekuler Indonesia, Desember 3, 1-10, UNRI Pekanbaru Riau.

4. Sumaryati Syukur, Rina Dahlyanti, Titi Sumanti, Helmi Arifin , Endang Purwati, Risfa Heri, 2006, Profil Kimia dan Biokimia Virgin Coconut Oil (VCO), Proseding Seminar dan Simposium Kimia LIPI, Jan 24, 1-8.

5. Sumaryati Syukur, Rina Dahlyanti, Titi Sumanti, Helmi Arifin dan Endang Purwati, 2005, Bioteknologi Virgin Coconut Oil, Peningkatan Kesehatan Total dan Pengentasan Kemiskinan Masyarakat Pedesaan, Seminar Terpadu Lembaga Pengabdian Masyarakat Univ. Andalas, Padang 14, 1-15. 
6. Enig, M. G., Atal,S., Sampugna J., dan Keency M., 1990, Trans Fatty Acids in the US Diet, J. Nutr., 9: 471- 486.

7. Kurup, P. A., Rajmohan T.H., 1994, Consumption of Coconut Oil and The Incidence of Atherosclerosis in Human Nutrition, Proceeding symposium on coconut oil, Kochi, India.

8. Deacon, A.C., and Dawson, P.J.G., 1979, Enzimatic Assay of Total Cholesterol Involving Chemical or Enzymatic hydrolysis -A Comparison Method-, Clinical Chemistry., 25 (16), 976-983.

9. Deeg, R., and Ziegenhorn, J., 1983, Kinetic Enzymatic Method for automated Determinated of Total Cholesterol in Serum, Clin. Chem., 29: 802.
10. Khosla, P., and Hayes, K.C., 1996, Dietary trans-mono-unsaturated fatty acids negatively impact on plasma lipids in humans, J. Am. Nutr., 15: 325-339.

11. Murray, R. K., 1989, Lemak, Metabolisme, dan Penyakit Jantung Koroner, Laboratorium Biokimia Fakultas Kedokteran Universitas Andalas., Padang.

12. Mensink, R. P., and Katan, M. B., 1990, Dietary Trans Fatty Acids, The New England Journal of Medicine., 323: 439445.

13. Bambang Setiadji., 2004, Virgin Coconut Oil dan Serangan Jantung, Trubus., 417: 127-127.

14. Bach, A.C., and Babayan,V.K., 1982, Medium Chain Triglycerides, Am. J. Clin. Nutr.,36:950-962. 